BULLETIN Bulletin hispanique

HISPANIQUE Université Michel de Montaigne Bordeaux

120-1 | 2018

Varia

\title{
La Linterna Mágica (1820)
}

¿una publicación olvidada de Sebastián de Miñano?

La Lanterne magique (1820), une publication oubliée de Sebastián de Miñano?

'The Magic Lantern' (1820), a forgotten work by Sebastián de Miñaro?

\section{Marieta Cantos Casenave}

\section{OpenEdition \\ Journals}

Edición electrónica

URL: https://journals.openedition.org/bulletinhispanique/5907

DOI: 10.4000/bulletinhispanique.5907

ISSN: 1775-3821

Editor

Presses universitaires de Bordeaux

Edición impresa

Fecha de publicación: 30 junio 2018

Paginación: 239-256

ISBN: 979-10-300-0298-0

ISSN: 0007-4640

Referencia electrónica

Marieta Cantos Casenave, «La Linterna Mágica (1820)», Bulletin hispanique [En línea], 120-1 | 2018,

Publicado el 01 enero 2022, consultado el 07 enero 2022. URL: http://journals.openedition.org/

bulletinhispanique/5907; DOI: https://doi.org/10.4000/bulletinhispanique.5907 


\title{
La Linterna Mágica (1820): ¿una publicación olvidada de Sebastián de Miñano?
}

\author{
Marieta Cantos Casenave \\ Universidad de Cádiz
}

L'objet de cet article est d'analyser la structure, le style et l'objectif du pamphlet satirique La Lanterne Magique, publié sans nom d'auteur en 1820, pour vérifier l'hypothèse selon laquelle il pourrait être une œuvre oubliée de Sebastián de Miñano.

Mots-clés : pamphlet, satire, Sebastián de Miñano, La Lanterne Magique.

Este artículo pretende analizar la estructura, el estilo y la finalidad del folleto satírico La Linterna Mágica, que se publica anónimo en 1820, con el fin de contrastar la hipótesis de que pudiera tratarse de una obra olvidada de Sebastián de Miñano.

Palabras clave: panfleto, sátira, Sebastián de Miñano, La Linterna Mágica.

The aim of this paper is to analyse the structure, style and purpose of the satirical pamphlet 'The Magic Lantern', published in 1820, in order to test the hypothesis that it could be a forgotten play Sebastián de Miñano.

Keyword: pamphlet, satire, Sebastián de Miñano, The Magic Lantern. 


\section{INTRODUCCIÓN}

Mientras escribía un trabajo sobre la influencia de los instrumentos ópticos en la literatura romántica ${ }^{1}$, me encontré con una referencia al opúsculo $L a$ Linterna Mágica publicado en 1820, donde se explicaba que su autor Justo Balanzá [sic] había publicado tres números, se relacionaba atinadamente con otros folletos de similar título y se resumía su contenido satírico². Más tarde caí en la cuenta de que este Balanzá podía corresponder al seudónimo "Justo Balanza», con el que Sebastián de Miñano y Bedoya había firmado las cinco Cartas críticas, que simultaneó con la publicación de los Lamentos políticos de un Pobrecito Holgazán, así que traté de confirmar esta posible autoría.

El primero que se refiere a La Linterna Mágica es Hartzenbusch, pero se limita a señalar que ha visto tres números de este periódico de 1820 y a dar los datos de imprenta, sin referirse a su autor, dado que se publicó como anónimo ${ }^{3}$. Tampoco La literatura española en el siglo XIX de Blanco, que reconoce ciertas dotes de satírico del autor de las cartas de El Pobrecito Holgazán y de las de Don Justo Balanza, menciona La Linterna Mágica ${ }^{4}$.

El que sí se refiere a ella es Renedo (1919) que, en el tomo II de los consagrados a los Escritores palentinos (Datos bio-bibliográficos), dedica siete páginas a Miñano y reseña La Linterna Mágica como la sexta entre sus publicaciones ${ }^{5}$. Sin explicar en qué fundamenta esta atribución de responsabilidad autorial, se limita a constatar que se publicaron tres números de 24 páginas y a ofrecer los datos de imprenta. La asignación de autoría no procede, desde luego, del perfil trazado por Eugenio de Ochoa, hijo de Miñano ${ }^{6}$,

1. Marieta Cantos Casenave, «Los dispositivos ópticos y su recepción en la prensa del Romanticismo (1835-1868). Una aproximación», Anales, 25, 2013, pp. 105-130.

2. Luis Miguel Fernández, Tecnología, espectáculo, literatura. Dispositivos ópticos en las letras españolas de los siglos XVIII y XIX, Universidad de Santiago de Compostela, 2006, p. 275.

3. Juan Eugenio Hartzenbusch, Apuntes para un catálogo de periódicos madrileños desde el año 1661 al 1870, Establecimiento Tipográfico "Sucesores De Rivadeneyra», Madrid, 1894, p. 30.

4. P. Francisco Blanco García, La literatura española en el siglo XIX, Parte Primera, Sáenz de Jubera, Madrid, 1909, p. 331. Tampoco parece haberla visto Julio Cejador y Frauca, Historia de la lengua y literatura castellana, tomo VI, Tipografía de la «Revista de Archivos, Bibliotecas y Museos», Madrid, 1917, p. 382.

5. Agustín Renedo, «Sebastián de Miñano y Bedoya», Escritores palentinos (Datos biobibliográficos (Imprenta Helénica, Madrid, 1919, T. II, pp. 146-152). Para La Linterna Mágica, cf. p. 150. El resto de referencias que aporta tampoco la mencionan.

6. «Sebastián de Miñano y Bedoya», Diccionario biográfico del Trienio liberal, Ediciones El Museo Universal, Madrid, 1991, pp. 435-438. Cf., también, Paleobiografía (1779-1819) del "Pobrecito Holgazán» Sebastián de Miñano y Bedoya. Universidad de Salamanca, Salamanca, 2002 y «Sebastián de Miñano y Bedoya», en Diccionario Biográfico de España (1808-1833). De los orígenes del Liberalismo a la reacción absolutista, Fundación Mapfre, Madrid, 2010. En este mismo Diccionario, en la entrada sobre Lorenzo José de Noriega y Ruiz, se le atribuye la autoría de La Linterna Mágica, cuando en realidad sus iniciales aparecen asociadas a la exposición con que se abre la Linterna mágica de la Constitución, publicada en México en 1820, folleto del que 
cuyos apuntes publicados en el Museo de las familias menciona entre sus fuentes. Para 1820, Ochoa anota:

Hubo una época, ya lejana de nosotros, en que el nombre de Miñano, saliendo súbitamente de la oscuridad, adquirió una gran fama en España y América: tal fue el segundo período constitucional, de 1820 a 1823, en que aquel escritor empezó a dar a luz bajo el pseudónimo del Pobrecito Holgazán, las preciosas cartas políticas de este título. Un solo hecho dirá más en este punto que cualesquiera reflexiones: reimpresas en casi todas nuestras capitales y en muchos puntos de América, puede calcularse sin exageración, que la tirada hecha de cada una de aquellas cartas pasó de 60,000 ejemplares. Esto que hoy sería enorme, era entonces enormísimo, monstruoso, y solo se explica considerando el verdadero entusiasmo que excitaron en el público; entusiasmo merecido sin duda, no solo juzgándolas en el concepto de escritos de circunstancias, sino por su sana doctrina, por su correcto y puro lenguaje, que alguna vez recuerda el de nuestro inmortal Cervantes, y sobre todo, como felicísimos cuadros de costumbres. Al mismo género pertenecen, y no menor aplauso obtuvieron, las Cartas del Madrileńo y las de Don Justo Balanza, que publicó por el mismo tiempo, aquellas en el excelente periódico El Censor, de que fue director y uno de los más asiduos redactores; estas en folletos sueltos como las del Pobrecito Holgazán, opúsculos que hoy nadie lee, porque la corriente de los sucesos y de los intereses se lleva la atención pública a otros lados, pero que, a nuestro humilde sentir, vivirán en la posteridad, y en los que, por lo menos, siempre habrá que reconocer el mérito de haber abierto en nuestros días la senda que luego han recorrido con tanto lucimiento, entre otros, el inolvidable Fígaro, El Estudiante y Fray Gerundio (Museo de las familias, Segunda Serie, tomo XVII, 1859, pp. 1-3).

Además de abundar en algunas Cartas del Pobrecito Holgazán, incluidas en los Opúsculos inéditos, para los años del Trienio añade las siguientes obras:

Reflexiones de un español dirigidas a S. M. sobre la situación actual de los afrancesados (mayo de 1820); y algunos otros folletos más (pues como folletos se publicaron en su tiempo, del 20 al 23, todos los escritos que dejamos referidos, por lo cual es muy difícil su adquisición), de polémica con un crítico muy conocido que, bajo el supuesto nombre de don Juan Álvarez, censuró tan acerba como injustamente su Diccionario geográfico. Suyas son también una traducción de la Historia de las revoluciones de la medicina, por Cabanis, que imprimió en Madrid en 1820 [...] (Idem, p. 3).

Menéndez Pelayo en su Historia de los Heterodoxos españoles, al ocuparse de los escritores afrancesados, destacó «el ingenio castellano de buen donaire, extremado en el manejo de la ironía» del autor de las «celebérrimas Cartas del Pobrecito Holgazán», de las que asegura:

Las Cartas van todas contra el régimen antiguo. Inquisición, jesuitas, diezmos, frailes (lechuzos eclesiásticos los llama), bulas y concesiones pontificias, cofradías y

también podría ser autor. Cf., Marieta Cantos Casenave, "En el foco de la linterna mágica periodística (1808-1865) ", La tribu liberal : el Romanticismo a las dos orillas del Atlántico, coord. por José Ma . Ferri Coll y Enrique Rubio Cremades, Madrid : Iberoamericana ; Frankfurt am Main : Vervuert, 2016, pp. 137-158. 
hermandades, libros de teología moral... van pasando por el rasero de un gracejo volteriano refinadísimo (a lo Moratín) bien traducido, y con aparente llaneza, al lenguaje de tierra de Campos?

En opinión de Berazaluce conviene precisar esta afirmación, pues considera que la crítica de los Lamentos -y la denuncia política de Mińano, en general- alcanza por igual a "blancos» y a "negros» ${ }^{8}$. Aunque el estudio de esta investigadora sigue siendo uno de los más completos -y remito a él para justificar mi exclusión de los trabajos de Aguilera Santiago-, tampoco documenta entre sus folletos La Linterna Mágica, pero me interesa retener esta matización a la opinión de Menéndez Pelayo sobre el alcance de la denuncia de Miñano que, también comparte Claude Morange.

Precisamente, de las primeras aportaciones de este investigador y de las de Jurestchke parte el trabajo de Castañón que considera las Cartas de Don Justo Balanza a un Pobrecito Holgazán, junto con las del "Lamentador" y las "Cartas de un madrileño a un amigo suyo de provincias" una "curiosa y continuada trilogía apasionada y entrecortadamente escrita por "Chano" en el breve período de un ańo»". Castańón ignora la existencia de La Linterna Mágica, pero cree que se han perdido un sinfín de cartas, más «un sinnúmero de artículos anónimos», entre ellos los que Jurestchke le atribuye en su Vida, obra y pensamiento de Alberto Lista. Aquí Jurestchke asigna a Miñano la autoría de los artículos "Elogio de la intolerancia política», "Cuatro palabras a los serviles», «Defensa de los medrosos», «Respuesta nada oscura», «Modelos de difamación», «Sobre los nuevos liberalismos» y «Un día de un jugador», publicados en $E l$ Censor ${ }^{10}$; pero tampoco menciona La Linterna Mágica.

Lo mismo sucede en el pormenorizado catálogo ${ }^{11}$ de Morange que tampoco la considera en sus estudios de los folletos publicados en el Trienio Constitucional ${ }^{12}$. No obstante, me interesan las cuestiones que afectan a la cronología de la obra de Miñano y su estilo, pues una consulta a la prensa coetánea ofrece una pista que relaciona a este autor con La Linterna Mágica.

Efectivamente, aunque los anuncios en La Periodico-Manía y en El Universal Observador Español de 4 de julio no ofrecen otros datos que la reseña de su

7. Marcelino Menéndez Pelayo, Historia de los heterodoxos españoles, Libro VII, capítulo III. Edición digital de la Biblioteca Virtual Miguel de Cervantes, 2003. [Página consultada el 7 de noviembre de 2014]. Disponibilidad y acceso http://www.cervantesvirtual.com/obra/historiade-los-heterodoxos-espanoles/

8. Ana María Berazaluce, Sebastián de Miñano y Bedoya: (1779-1845), Ediciones Universidad de Navarra, 1983, p. 144

9. Jesús Castañón, «Sebastián de Miñano: un periodista del período liberal», en Anales de Literatura Española 2 (1983), pp. 83-102.

10. Hans Jurestchke, Vida, obra y pensamiento de Alberto Lista, CSIC, Madrid, 1951, p. 409.

11. Claude Morange, «Sebastián de Miñano. Ensayo de catálogo crítico de sus obras», Trienio - Ilustración y liberalismo (Madrid), nº 21 (1993), pp. 99-128, y n 23 (1994), pp. 5-40.

12. Claude Morange, Sebastián de Miñano: sátiras y panfletos del Trienio constitucional (1820-1823), (Selección, presentación y notas de Claude Morange), Centro de Estudios Constitucionales, Madrid, 1994. 
contenido, en la nota de la Miscelánea de comercio, politica y literatura, de 29 de junio de 1820, tras avisar de que se vende «en la Librería de Paz, frente a las gradas de san Felipe, a trece cuartos», se añade un detalle significativo:

El autor se propone dar a luz algunos folletos del tamaño de las Cartas del Pobrecito Holgazán, y en ellos ir bosquejando escenas entretenidas y graciosas, que retraten al vivo las manías y extravagancias de algunos hombres de estos tiempos. Según parece, no habrá cosa ridícula que se escape de su censura, en la cual, como se declara en la introducción, nunca se descubrirá el menor rastro de sátiras personales.

El estilo tiene aquella especie de abandono, que cuadra perfectamente a los escritos de esta clase (p. 4).

Si no hay referencia explícita a la autoría de Miñano ni esta alusión descarta que fuera obra de un imitador, ciertas coincidencias en la composición, temas y estilo de este folleto, comparados con los de las sátiras y panfletos tan minuciosamente analizados por Morange ${ }^{13}$, me parecen suficientes para proceder a su análisis. No es extraño, en todo caso, que el texto haya pasado desapercibido, pues Mińano llegó a escribir unos 200 folletos o artículos periodísticos, casi todos anónimos, entre marzo de 1820 y julio de $1822^{14}$. Además, en el fichero manual de la Biblioteca Nacional, la entrada que localiza La Linterna mágica de 1820 remite a la ficha de las "Cartas Primera-Quinta» de Justo Balanza, localizadas, bajo la signatura U - 11064 del fondo Usoz, en un volumen facticio que contiene a continuación de las cartas, La Linterna mágica. Tras esta están encuadernadas Otra carta consolatoria al pobrecito holgazán por otro que ha trabajado mucho en la discordia de los ciudadanos (imprenta de la Viuda de Barco López, 1820), firmada por El ex-pretendiente a mitras; Reflexiones de un español, dirigidas a $S$. M. por mano del General Don Felipe Arco-Agüero, sobre la situación actual de los afrancesados (imprenta de Fuentenebro, 1820); las Condiciones y semblanzas de los Diputados a Cortes para la legislatura de 1820 y 1821 (imprenta de Juan Ramos y compañía, 1821); y Otra carta blanca sobre el negro folleto titulado Condiciones i semblanzas de los Diputados a Cortes, firmada por el licenciado Palomeque (imprenta de M. de Burgos, 1821), que es respuesta de Gallardo a la atribución que le hicieron de la autoría del folleto anterior. Aunque no todos los reunidos en el volumen son obra de Miñano, sí que están relacionadas con él, lo que parece indicar que Luis Usoz la consideró como obra del palentino. Me dispongo, pues, a examinar esta publicación para analizar su género, qué asuntos aborda y con qué intención dirige el autor el foco de La Linterna Mágica.

13. Idem, pp. 33-47.

14. Idem, p. 24. 


\section{LA LINTERNA MÁGICA, UN FOLLETO CUASI-PERIÓDICO}

De La Linterna Mágica publicada en 1820 en la Imprenta de Rosa Sanz, situada en la madrileña calle del Baño, existen tres números en $8^{\circ}$, tanto en la Biblioteca Nacional, como en la Hemeroteca Municipal de Madrid y en la Real Academia Española. Se vendía a trece cuartos en la librería de Paz, precisamente la misma en la que se vendían las Cartas de Don Justo Balanza.

Si mi hipótesis es correcta, probablemente los tres números de La Linterna Mágica vieron la luz al mismo tiempo o poco antes que la "Carta tercera de Don Justo Balanza», publicada a finales de junio y anunciada por la Miscelánea el día 3 de julio, mientras que la "Carta cuarta» lo sería a mediados de julio, coincidiendo prácticamente con la última entrega de La Linterna Mágica, lo que podría dar pie a considerar que Miñano había volcado en el linternista "Justo Balanza» su personalidad más burlona, mientras responsabilizaba al corresponsal homónimo de la crítica más seria.

Aún existen otras conexiones entre estas series epistolares, calificadas en ocasiones como "cartas periódicas», y La Linterna Mágica, a la que su autor designa en la "Introducción» como "periódico», para asegurar irónicamente luego: «Tampoco puedo decir la época fija en que saldrán a luz los números sucesivos, porque como soy yo solo el que lo ha de escribir, y no tengo la salud, ni aun la vida segura, no quiero ofrecer lo que no sé si podré cumplir». En esta línea, El Universal Observador Español al anunciarlo el 4 de julio, insiste en la falta de compromiso con la periodicidad:

El autor de este papel, que saldrá cuando a él se le antoje, y le dejará cuando le diere la gana, se propone divertir al público con su linterna, e instruirle con las escenas que representará en ella. El numero I se compone de cuatro. En la primera viene a sacarse que los hombres siempre serán hombres; es decir, que el sirviente busca empleo, y el servido tiene que darle. En la segunda pinta tres caballeros negros que antes estaban gordos porque comían a dos carrillos, y aun ahora andan buscando medio para no perder la buena costumbre. En la tercera describe con gracia la magia de las actuales circunstancias, y zahiere con sal a los que toman la voz de la opinión pública para sus fines. La cuarta y última pinta bonitamente los efectos de la avaricia, que aunque vea perecer la patria, vuelve al cofre sus duros, porque no le producen un interés usurario (El Universal Observador Español no 54, 4 de julio de 1820, p. 198).

La Linterna Mágica, como los Lamentos, es, pues, un folleto no periódico, o -como dicen los coetáneos- sin periodicidad fija, que en estas fechas no parece diferenciarse mucho de los que sí la tienen. Así lo entienden todavía en 1822 los redactores de El Censor, al dar la bienvenida a las Espabiladeras: "Tres números hemos visto de un folleto que sin periodo fijo se publica en Valencia [...]», de cuyo autor señalan más adelante: «el nuevo periodista, cual diestro cirujano, descubre todo el vendaje, mete la tienta hasta el cabo, levanta las escaras y descubre hasta el fondo de las úlceras cancerosas con que un 
liberalismo desatinado ha llegado a infestar a algunos habitantes de Valencia» ${ }^{15}$. Basta, pues, que el folleto concierte citas sucesivas con el lector, sin importar si la periodicidad es fija o no, para considerarlo periódico y para que su autor pueda ser calificado como "periodista». No es una novedad, pues también la Periódico-manía había sido saludada por la Miscelánea del comercio como folleto sin período fijo, lo que demuestra la frágil frontera que en estas fechas existía entre ambos formatos, a los que indistintamente solía referirse Miñano, lo mismo que otros compañeros de El Censor, como "escritos volantes»" ${ }^{16}$.

Además la extensión de La Linterna Mágica es similar a la de las Cartas del Pobrecito Holgazán, pues si las entregas de los Lamentos tienen unas veinte páginas en $8^{\circ}$, La Linterna Mágica alcanza las veintitrés para la primera, veinticuatro para la segunda y veintidós para la tercera, también en $8^{\circ}$. La novedad, respecto a otros folletos de Miñano, radica precisamente en la sustitución del formato epistolar por la narración de una función de esta clase de máquina óptica, precedida en cada caso de un texto preliminar que recibe diferentes nombres y extensión. La primera incluye ocho páginas de «Introducción»; la segunda, tres de «Prefacio» y la tercera, la más corta, poco más de dos páginas de «Discurso preliminar». La mayor extensión del primero de estos textos se justifica porque la «Introducción» funciona como prólogo general de la obra y en él se contiene lo que podría considerarse como el germen de la poética de La Linterna Mágica.

\section{PoÉtica de LA LINTERNA MÁGICA.}

El GUSTO DEL PÚBLICO Y LOS DIGNOS LÍMITES DE LA SÁTIRA

Miñano, harto quizás de sentirse incomprendido, pero satisfecho del éxito de sus Lamentos, se está replanteando a la altura de la carta sexta -mayo de 1820- el valor de la estrategia del ridículo. Al final de la primera de las Cartas de don Justo Balanza, se lee una declaración que puede interpretarse como una justificación al cambio de rumbo iniciado en esta nueve serie epistolar, que marca también su distanciamiento de la retórica satírica del «Lamentador»:

Todo público gusta de burlas, pero no todos las entienden todas y hay objetos en que la más leve equivocación induce a errores funestos. Yo también sé chancearme, porque, como decía Cervantes en boca del canónigo, toda mi vida fui aficionado a la farándula; pero al paso que procuraré imitar el estilo de usted y aun acaso sus ideas sobre ciertos objetos, sabré también revestirme de severidad en otros, y no tendré más compasión con usted mismo que la que usted ha tenido con los demás. El público imparcial desea que se le hable con confianza y que se le muestren las cosas como son

15. El Censor no 91 de 27 de abril de 1822, p. 37.

16. Claude Morange, Sebastián de Miñano: sátiras y panfletos del Trienio constitucional (18201823), p. 49. Todas las referencias a las Cartas del Pobrecito Holgazán y a las Cartas de Don Justo Balanza se realizarán por esta edición. 
en sí para darlas el valor que se merecen. Usted ha sabido agradarle hasta ahora, pero es necesario que sepamos si este aplauso es un triunfo de la razón, o si es efecto de los colores demasiado vivos de que ha usado usted en sus pinturas ${ }^{17}$.

Sin embargo, también es cierto que las Cartas de don Justo Balanza que se publicaron entre mediados de mayo y principios de agosto, quizás por un exceso de seriedad ${ }^{18}$, no tuvieron el mismo éxito que los Lamentos. Tal vez por ese motivo o bien porque, como el mismo «Justo Balanza» escribe al Pobrecito Holgazán al principio de la Carta quinta, «no son ya muchos los que nos quedan de aquellos [asuntos] que por su importancia merecen un repaso detenido» ${ }^{19}$, Mińano desistió de publicar una nueva entrega, a pesar de que solo tenía que entresacar los temas de los Lamentos y reelaborarlos con mayor seriedad y profundidad.

Quizás, dado que Miñano, al tiempo que comenzaba la serie epistolar de "Justo Balanza», publicaba los folletos en que impugnaba a Chateaubriand, discurría sobre la libertad de imprenta y reflexionaba sobre la situación de los afrancesado ${ }^{20}$, decidió cultivar una sátira menos agresiva, más «equilibrada» de la mano del linternista, lo que le permitía además atraerse de nuevo el favor del público.

Esa sátira suave es, al menos, la que se propone el autor de La Linterna Mágica, como advertía el anuncio del no 3 de la Miscelánea:

El autor de este papel continúa censurando en estilo agradable, festivo y puro las maulas y ridiculeces de toda clase de personas, sin que se deslice jamás a ninguna sátira personal y grosera. Para merecer la aceptación del público no es el verdadero camino echar mano de las injurias, que nunca leen con gusto las personas bien educadas, ni sientan bien a ciudadanos que solo deben consultar en sus escritos al bien y prosperidad de la patria. Estas dotes apreciables que se advierten en el papel que anunciamos, unidas al mérito de la invención de un honesto pasatiempo, harán leer con interés la Linterna Mágica (Miscelánea de comercio, política y literatura del 15 de julio de 1820 , p. 2).

El aviso publicitario solicita al lector que la crítica jocosa sea interpretada al modo de la sátira horaciana, distanciándose así de la más acre que tuvo por modelo a Juvenal. Pero no siempre es fácil alcanzar este objetivo, dada la variedad del público, la diversidad de su gusto y la distinta interpretación que pueda hacer cada lector. Estas dificultades se abordan precisamente en la «Introducción», donde, a modo de poética, el autor trata de explicar ese difícil equilibrio que consiste en interesar al lector, sin recurrir a la fórmula fácil de la sátira personal -como reclama también "Justo Balanza»-, en un momento en que la competencia es grande, desde que se proclamara nuevamente la libertad de imprenta y todos los escritores vieran en ella una posibilidad de lucrarse, como igualmente había señalado Miñano.

17. Cf., Carta primera de don Justo Balanza, idem, p. 203.

18. Claude Morange, Sebastián de Miñano, op. cit., p. 25.

19. Carta quinta de don Justo Balanza, idem, p. 233.

20. Claude Morange, op. cit., p. 26. 
Resulta obligado, pues, buscar una estrategia comercial que logre una estudiada novedad en la elección del título y de las palabras del prospecto, entre «tantos y tan ingeniosos los títulos y formas bajo que han aparecido, y tantas y tan bien pensadas las cosas que sus autores han dicho en los prospectos, introducciones o prólogos para picar la curiosidad de los lectores» (p. 3). Sin duda, un recurso de la captatio benevolentiae, que no deja de traslucir, no obstante, el estado efervescente de una opinión pública a la que tratará de seducir, en unos años en los que precisamente Miñano aspiró a vivir de la escritura.

Socorrida estrategia retórica es también la construcción de la máscara ficcional con la que se presenta el autor, «escritor con tal fuerza que no puedo contenerme ni irme a la mano" (p. 5) y con "caudal suficiente» de noticias "para henchir un tomo en folio, no que un triste folleto, que es lo que está en boga» (p. 4). El resto del autorretrato lo aleja tanto del corresponsal "Justo Balanza» como del «Lamentador»:

Con poca instrucción y menos constancia para las obras serias y de grande aliento; con una propensión tan irresistible a la risa, que hay pocas cosas en este mundo que no me muevan a ella; con un prurito de charlar que parece que me falta tiempo; y, por un contraste muy particular, con la mayor aversión a zaherir y ofender a nadie [...] ( $\mathrm{La}$ Linterna Mágica ${ }^{\circ}$ 1, p. 5-6).

Desde luego, esa poca instrucción y esa falta de constancia no se corresponden con la realidad de Miñano, pero sí con la de muchos periodistas y escritores públicos que se lanzaban a la aventura literaria. En todo caso, en medio de las bromas, el autor marca los límites de su burla en la línea de lo que pretendía el ilustrado, al dignificar el ejercicio de su sátira. Efectivamente, rechaza recorrer los caminos de la ofensa y el escarnio público, al que tan acostumbrado estaban los lectores -entre ellos los de Miñano-durante el Trienio. En este contexto hay que entender las distancias que el autor marca con la fórmula del éxito que, sin embargo, tantos disgustos había procurado al autor de los Lamentos y de otros folletos y periódicos satíricos:

Si yo quisiera que mi papel fuese leído de todo el pueblo de esta Capital y de algunas otras de España, no tenía más que enredarme con un par de ministros, tres o cuatro consejeros de Estado, algún general, jefe político, togado u otra persona constituida en alta dignidad, llenarlos de denuestos, calificarlos de ignorantes, malvados o desafectos a la Constitución; acusarlos de que de muchachos tiraban piedras, de mozalbetes cortejaban, hacían versos y daban músicas; jugaban de adultos y se embriagaban en los banquetes; y ya de hombres hacían la corte a los poderosos, intrigaban y maquinaban para progresar en la carrera de la ambición; y por último inventar algún lance o historieta ridícula y achacársela para hacer reír a su costa. ( $L a$ Linterna Mágica $\mathrm{n}^{\circ}$ 1, p. 5)

Si esta es la fórmula "para dar salida a un escrito en estos días», el autor de $L a$ Linterna Mágica insiste una y otra vez en que aspira a alcanzar un equilibro que le permita ser leído por todo tipo de público y en particular por personas «bien educadas», que no gustan de leer injurias y de "ciudadanos que solo deben 
consultar en sus escritos al bien y prosperidad de la patria», o que procuren en su lectura un "honesto pasatiempo», como advertía el anuncio del no 3 . Por eso anda con tiento y presta atención a lo que el público demanda: «un papel que no sea muy largo y que tenga su sal y pimienta», aunque luego añade con ironía: «De esto se puede cargar la mano sin el menor recelo, pues los estómagos están tan abundantes de jugos y tan ávidos de materia en que ejercitarse, que nada repugnan, antes bien el picantillo templa y corrige la incitabilidad [sic] acumulada (p. 4)».

La tentación es grande, como también el peligro de incurrir en la sátira personal, por eso recurre a la fórmula de la linterna mágica, que le permite «variar las escenas» a su gusto, «multiplicarlas al infinito» y «transportarlas al lugar que más convenga» (p. 6), para compensar la limitación del picante. Como «El Lamentador», el autor es consciente de que, a pesar de que procure que nadie se sienta satirizado particularmente, el lector puede ver ciertas claves donde no las hay:

Esto no obstante para descargo de mi conciencia y tranquilidad del prójimo debo advertir que jamás tendrá lugar en ellas ningún hecho real y verdadero, sino que todos cuantos se representen serán fingidos, así como figurados los personajes, exagerados los caracteres, y cargado el colorido para alejar toda sospecha de que pueda ser mi ánimo designar, ni atacar a persona determinada. Si a pesar de esto alguno por desgracia se viese retratado no será culpa de mi intención, que seguramente no peca de bellaca, sino efecto de una combinación casual de circunstancias, poco común en la naturaleza, ya que no sea imposible (La Linterna Mágica no 1, pp. 6-7).

La visón del mundo, del referente externo que sugiere el texto, plantea un realismo intencional ${ }^{21}$, propone una representación de la realidad que es completada por la visión del mundo externo que cada lector proyecta y que puede diferir de la prevista por el autor. A ello se añade la oblicuidad característica de la sátira, que busca censurar no directamente sino mediante una serie de recursos literarios que deben ser correctamente interpretados por el lector, lo que dificulta su eficacia para corregir los errores que ridiculiza.

Al presentar el texto como una proyección de linterna, su estructura se plantea como una serie de funciones compuestas de diferente número de escenas, que exigen ser presentadas por un narrador que hilvane con su charla la sucesión de escenas yuxtapuestas. En realidad, dada la escasa calidad de las imágenes proyectadas por este tipo de instrumentos ópticos, el linternista, que con frecuencia es caracterizado como charlatán -rasgo que comparte con la máscara ficcional del narrador de La Linterna Mágica- es la fuente última que da sentido al relato "proyectado». El folleto presenta en realidad a un doble narrador, el narrador externo que unifica el relato y el narrador interno, el titiritero Maese Pedro, que es también el responsable de la proyección de las escenas.

21. Darío Villanueva, Teorías del realismo literario, Instituto de España / Espasa Calpe, Madrid, 1992, p. 119. 
El «Prefacio» de la entrega no 2 insiste en los problemas de la recepción. En primer lugar, señala las dificultades para lograr el éxito comercial, como advierte el narrador a Maese Pedro: «para ganar hoy una peseta es preciso remar y echar los bofes, que anda el dinero muy estirado y ya no hay bobos en Sayago. Trate usted de dar esta mańana una buena función porque si no se retirarán los espectadores y la linterna se quedará a oscuras». Por otra, destaca las exigencias y suspicacias del variado público a que va dirigido. Maese Pedro, que como muchos titiriteros es extranjero, malinterpreta al narrador, al creer que le está pidiendo acerar más su crítica «y por dar a usted gusto me esforzaré a levantar la voz de punto"; pero el narrador, por el contrario, le pide que se ande con tiento «y no se meta en dibujos, que somos hijos de muchas madres, y hay quien se ofende hasta del aire que le rodea». El titiritero promete no incomodar a nadie, pero avisa:

[...]; pues ha de saber vd., que han venido algunos a azuzarme para que diese a las escenas y a los personajes un poco más de movimiento y de verdad y me he negado abiertamente, diciéndoles que no era mi ánimo retratar a ninguna persona en particular, y mucho menos con sus pelos y señales, sino bosquejar en general y en tamaño gigantesco el carácter y las opiniones de ciertas gentes que frecuentemente tropieza uno en la sociedad imposible (La Linterna Mágica no 2, pp. 4-5).

Así pues, la luz distanciadora que proyecta la linterna, al agrandar y desdibujar los rasgos, permite un bosquejo general de algunas personas -carácter y opiniones- de la sociedad, sin adentrarse en la pintura particular, que no puede ser objeto de la sátira. Poco añade el «Discurso preliminar» del $\mathrm{n}^{\circ} 3$, pues se limita a apostar por la variedad como estrategia necesaria y útil para satisfacer el gusto.

En fin, la estructura narrativa de la linterna le permite proyectar su sátira, concebida como una sucesión de imágenes, a menudo yuxtapuestas, y poco definidas -en bosquejo- y agigantadas -como lo eran, en realidad, las proyectadas por este aparato-, sin incurrir en la invectiva. Esta representación no pretende ofrecer un cuadro general de la sociedad, sino apuntes de caracteres y opiniones comunes a una serie de individuos, en la línea de los que esbozan algunos artículos de Miñano en $E l$ Censor. Efectivamente, entre los que Morange señala como obra suya, «Sobre la verdadera aplicación de la palabra "tontos"” (17 e marzo de 1821, 181-192) y "Una platiquita sobre la vanidad $\aleph^{22}$ presentan algunas similitudes estructurales. Es decir, en ellos proyecta una "galería de cuadros», expresión usada por el Madrileńo para calificar también los que esbozó para los Lamentos políticos de un Pobrecito Holgazán («Explicación que da el autor de las cartas del Madrileño sobre el verdadero sentido de la carta 13a», El Censor, 3 de marzo de 1821, p. 55).

Al mismo tiempo, se trata de una representación ficticia de escenas y personajes que, para evitar el retrato personal, exagera los caracteres y «carga el colorido", es decir plantea una pintura deformadora, caricaturizadora, propia

22. Claude Morange, op. cit., pp. 38 y 57. 
de la sátira. El mismo Miñano, al hablar del proceder del Madrileño en sus cartas, usa palabras muy similares a las que utiliza el autor de La Linterna Mágica:

[...] y si alguna vez ha empleado los colores más fuertes de la sátira, ha sido siempre con ocasión de corregir yerros, o para evitar faltas de primer orden. No ignoraba el autor que su lenguaje parecería excesivamente amargo a los que cierta o equivocadamente creyesen haber servido de modelo para el cuadro; pero en el primer caso era esta su verdadera intención, y en el segundo, claro es que no se le deben imputar semejanzas involuntarias («Explicación que da el autor de las cartas del Madrileńo sobre el verdadero sentido de la carta $13^{a}$, El Censor, 3 de marzo de 1821, p. 57).

Ahora bien, las fuentes de la sátira de La Linterna Mágica no se agotan en la obra de Miñano, sino que es fácil reconocer ciertos ecos de Quevedo, así como resonancias más directas de la obra de Cervantes. A este respecto, y aun cuando pudiera considerarse que esta influencia se limita al desengaño del públicolector, cabe señalar que no parece casual que un nuevo Maese Pedro, también titiritero como el personaje del Quijote, sea el encargado de hacer funcionar la máquina portentosa.

\section{UN NUEVO RETABLO DE MARAVILLAS}

No es nueva, desde luego, la presencia de Maese Pedro, pues ya otro cultivador de la sátira, Torres Villarroel, había establecido la conexión entre este máquina óptica y su variante popular, el mundonuevo, con el retablo de las maravillas cervantino ${ }^{23}$.

En La Linterna Mágica, el particular funcionamiento de este aparato óptico aconseja que, cuando comienza la primera función, Maese Pedro, en lugar de ocultarse tras el retablo, se sitúe delante de la representación, en la posición que ocupaba el ayudante del titiritero cervantino. En vez de la varilla, Maese Pedro enristra ahora la linterna, el arma moderna que le permite apuntar en cada función diferentes espacios madrileños, todos ellos reconocibles por el público, por ser muy frecuentados y, por ello, escenarios los más idóneos para desvelar la realidad que permanece oculta a simple vista: "Al levantar el telón aparece la calle Mayor en perspectiva. Maese Pedro, colocado en medio de ella con su linterna delante de la casa del conde de Ońate, levanta la voz en alto y dice: ahora verán, Señores, una gran variedad de personajes...». La proyección de la linterna necesita de un narrador capaz de reforzar la ilusión de realidad con que atrapa al público-lector y de sostener el encanto con la habilidad de

23. Germán Labrador Méndez, «La televisión del siglo XVIII. Retablos de maravillas y linternas mágicas en un pronóstico de Torres Villarroel y un dibujo de Goya». Edición digital de la Biblioteca Virtual Miguel de Cervantes, 2009. [Página consultada el 7 de noviembre de 2014]. Disponibilidad y acceso en http://www.cervantesvirtual.com/obra/la-television-delsiglo-xviii-retablos-de-maravillas-y-linternas-magicas-en-un-pronostico-de-torres-villarroel-yun-dibujo-de-goya--0/ 
su charlatanería. Con este fin, Maese Pedro promete que, además de admirar trajes y discursos, podrán ver lo que los personajes que deambulan por este espacio mágico tienen en sus pensamientos, reclamo con el que consigue llamar la atención de «un numeroso concurso» (p. 9).

Porque, como trataré de mostrar, la maravilla que descubre la luz de la linterna es la de alumbrar las verdaderas razones que mueven a hombres y mujeres, los motivos que revelan su carácter, su auténtica razón de ser. La ambición de una dama que rehúye al paje que la cortejaba porque piensa que, al perder poder su amo en estos tiempos constitucionales, el joven no conseguirá el empleo con que sońaba, es lo primero que deja al descubierto esta primera entrega. Pero no menos ambiciosa y oportunista resulta la respuesta del joven: «desde que el Rey la juró todos hemos visto emplear a más de cuatro que no tienen más letras ni más méritos que yo». Así que, animado con esta circunstancia, asegura que sabrá averiguar las debilidades de los poderosos, para «aprovechar los momentos y ganarnos su voluntad» (12-13). En la II escena, tres hombres, que en el Antiguo Régimen solían comer «a dos carrillos» y gozar de buen sueldo y pensión, maduran la forma de recuperar los privilegios que les quitó la Constitución. Son los pancistas, despectivo con el que el autor los vuelve a designar en la segunda entrega y que se puso de moda entre los liberales, a partir, fundamentalmente de su uso en la Abeja española de la que Bartolomé José Gallardo -ahora rival de Miñano- era redactor. La escena III dirige su foco al portal de Manguiteros, donde se saludan dos caballeros. El ministro le ha negado al primero lo que había solicitado "por las actuales circunstancias». El segundo le aconseja vengarse de él, acusándolo de dejarse corromper, y procurar desacreditarlo ante la opinión pública, ofreciéndose él mismo para ayudarle a tomarse la revancha. En la IV, aparece por Correo un comerciante que se disponía a hacer un préstamo al estado, hasta que lee un periódico donde se discute sobre el interés que se les debe abonar; esto le hace cambiar de idea, con la excusa de no tener que pasar por usurero ante la opinión.

Al comenzar la escena primera de la segunda entrega Maese Pedro parece identificar la linterna con un retablo mágico: «acérquense ustedes si gustan de primores, y verán maravillas en esta mi linterna mágica». Y para ganarse el concurso del público promete no ocuparse ya de "dueńas y escuderos, pancistas, pretendientes y adinerados», sino de "gentes de más alto coturno». La galería de caracteres la conforman ahora en primer lugar los moderados y los «exaltados o ultra-liberales» que batallan en la iglesia de San Luis espetando al rival un discurso en contra o a favor de recortar la libertad. La escena II está protagonizada por unos danzarines aduladores, especialistas en bailar no a un son "sino a todos los que les tocan» para mantenerse con cualquier gobierno del signo que fuere. Son los «cambia-colore» que Mińano había fustigado un par de meses antes en la carta V de los Lamentos. La escena III se propone retratar a una especie próxima que «al cabo son también de la familia de los aduladores», pero con una diferencia muy notable, que merece «clasificarlos aparte»: 
Estos caballeros tan aseados y compuestos; que miden los pasos y las palabras, y que acompañan estas con ciertos estudiados movimientos de cejas, ojos y boca, aspiran a la plaza de sabios constitucionales. Cuatro especies enciclopédicas mal amasadas, dos docenas de frases redondas y sonoras, y algunos versos, y no es de los mejores, componen todo su ajuar. Hablan poco, porque en pocas materias pueden hablar por falta de conocimientos $y$, cuando lo hacen regularmente, es para aprobar o pronunciar una sentencia definitiva, pues se inclinan más a decidir que a proponer. El tono, la voz, lo hueco de las palabras, el gesto y los ademanes les hacen creer no solo a muchos de los que los escuchan, sino tambien a ellos mismos, que son unos oráculos. Sin embargo, tienen la propiedad de no vituperar a nadie en esto de ciencia, antes por el contrario, para ellos todos son grandes hombres; y si viene a la mano pondrán en un parangón al inmortal autor del Quijote, y al de Bertoldo y Bertoldino, y hablarán con la misma veneración de la vida de San Benito de Palermo en seguidillas, que de las de los hombres ilustres de Plutarco.Como ellos son pigmeos, todos los demás les parecen gigantes $y$, aunque en esto descubren el secreto de su estatura, sin embargo suelen alucinar a la multitud (La Linterna Mágica, no 2, pp. 14-15).

Al final incluye un chascarrillo para ridiculizar la cultura de estos personajes, a los que Maese Pedro había denominado antes «áulicos», para designar a estos cortesanos sin mérito ${ }^{24}$. La escena IV está protagonizada por un editor de un periódico - «el liberal de poco acá»- que así enmascarado pretende recomendar a sus familiares. La escena $\mathrm{V}$ alumbra al reverso de los danzarines, los «descontentadizos», que no encuentran nada bien y maldicen el pasado "así como ahora reniegan del orden actual de cosas», del que rechazan tanto la opinión pública, como «la monotonía y pesadez del orden, que todo lo aplasta».

La tercera entrega de La Linterna Mágica proyecta una "Escena única» que se desarrolla en el Prado. En esta ocasión la linterna ilumina una galería de caricaturas que inicia una pareja de elegantes, en la que el caballero se queja por la forma en que lo trata la joven y ella le replica que hasta el amor cambia con la política: «si antes estimaba a usted a lo servil, hoy le estimo a lo liberal». Dos caballeros discuten luego sobre la diferencia entre lujo y apariencia, pues de la que se ostenta en la Corte $-y$ por la que se empeñan hasta los que no tienen- podría deducirse que hay una riqueza que no existe. A continuación dos señoritas comentan la rareza de sus respectivos novios, ya que la primera apenas puede mantener con el suyo -un liberal interesado solo en política- una conversación, al contrario que la segunda, que tiene por novio a un absolutista que, por no oír de Constitución, no se separa de ella. Seguidamente, un landó acerca a unas señoras que solo se ocupan de modas y luego asoman unos cortesanos que chismorrean sobre lo que traman ministros, señoras y caballeros para medrar, a resultas de los cambios operados por el sistema constitucional. Llega entonces un alto personaje, que habla «a manera de oráculo», con el aplauso cabal de los que le siguen, porque «esperan protección y saben que la

24. Un artículo comunicado en la Crónica científica y literaria de 21 de abril de 1820, al hablar de los personajes que mantenían a Fernando VII en la ignorancia, señala: «Nuestro Monarca, rodeado de áulicos egoístas y rapaces, que hablando con el célebre Mariana, son peste tanto más peligrosa cuanto más halagüeña y blanda». 
complacencia servil es aun hoy el medio de alcanzarla». Se ridiculiza luego al director de un periódico, que explica la fórmula que deberán seguir los editores para rellenar sus páginas:

[...] pasarán revista a todos los escritos de este género nuevo [el churripampli ${ }^{25}$ literario, que da nombre al periódico], que no son pocos, deteniéndose en los que se han publicado últimamente y publiquen en esta capital. Copiaran al pie de la letra los trozos enteros que lo merezcan, de los cuales tienen una mina en algunos periódicos; extractarán otros, y todos los anotarán con reflexiones crítico-filosófico-gramáticas ( $\mathrm{La}$ Linterna Mágica, no 3, p. 16).

Seguidamente, el diálogo descubre la ambición de un pretendiente, que aspira a una plaza ocupada. Su acompańante le propone la maledicencia para desacreditar como anticonstitucional al empleado y ocupar su puesto. Se escucha finalmente la conversación que mantienen otro pretendiente y el caballero que se sienta a su lado, a propósito de la próxima colocación que espera. El pretendiente no parece conformarse con cualquier puesto y, ante tanta reticencia, el caballero lo desenmascara como a un fanfarrón.

Si Miñano en los Lamentos se había propuesto la pintura de vicios y males del Antiguo Régimen, estas torpezas y corrupciones habían florecido nuevamente en la etapa constitucional y sobre esta realidad encubierta alumbra La Linterna Mágica, a modo de nuevo "Retablo de las Maravillas», donde se representa a toda la sociedad, todo el mundo que trata de mostrar una apariencia que nada tiene que ver con la realidad. Como justifica el Madrileño en El Censor, la Constitución no había acabado con los males antiguos y por eso las circunstancias del presente constituían el caldo de cultivo necesario para excitar la crítica:

Entretanto se fue desplegando una multitud de vicios y desórdenes, que aunque directamente no tendiesen a la destrucción del sistema, lo iban desacreditando con tal priesa, que hasta las personas más vulgares percibían su notoria decadencia. La ambición sobre todo se presentó bajo mil formas diferentes, y fue cundiendo de tal modo entre los más acreditados liberales, que ella sola hubiera bastado para hacer retroceder el espíritu de la nación, si el servilismo no hubiese dejado unos recuerdos tan funestos en todos los españoles.

Acompañaron a la ambición la ruin venganza y la feroz maledicencia, disfrazadas una y otra con la máscara del bien público, y al paso que lograron despojar de sus destinos a muchos ciudadanos beneméritos, introdujeron el odio en muchos pechos indiferentes, la frialdad en otros, la desesperación en algunos y la desconfianza en todos. («Explicación que da el autor de las cartas del Madrileño sobre el verdadero sentido de la carta 13a», El Censor, 3 de marzo de 1821, p. 57).

Ambición, venganza, maledicencia, adulación, hipocresía, travestismo político, son también las denuncias de La Linterna mágica.

25. Existe una jácara del XVIII, dedicada al parecer a un tipo de vino, que lleva por título «Curiosa jácara que declara la vida y la muerte del churripampli», Imprenta Luis de Ramos, Córdoba, s.a. 


\section{El apagón de La LiNTERNA MÁGICA. A MOdo DE CONClusión}

Si no son nuevos los asuntos de La Linterna Mágica, tampoco lo son la ironía y la «chanzoneta» con que los envuelve. Es más, creo que son reconocibles algunos rasgos de estilo con que «El Lamentador» conquistó al público ${ }^{26}$. De esta índole son alguna muestra la reproducción del lenguaje coloquial, que salpica de interjecciones e interrogaciones los diálogos: «itoma!», «¿faltan hoy amos a quienes servir?», «icuerpo de tal!», «imira tú qué entenderé yo de lógica ni de calabaza!»; símiles e hipérboles castizas: «tan raro como el ave fénix», una levita «más raída que sotana de sopista de Salamanca», fórmulas fijas como "hízola cocos», "huyes el basto», "me duermo en las pajas», «llenar la andorga», "comiendo a dos carrillos», «a humo de pajas», «harán el mismo caso ... que de las coplas de Calainos», «no sabe dónde tiene la mano derecha», «sin pararse en pelillos», "a tiro de ballesta», "el país de cucaña», "es preciso remar y echar los bofes», "ya no hay bobos en Sayago», «la carabina de Ambrosio», «jugar una pasada de clérigo mulato». Tampoco faltan expresiones ingeniosas como las «sardinas a la cachucha», el «menudo a la glutinosa», o los «tontíficos garbanzos». Usos todos ellos que, en mi opinión, siguen muy de cerca los utilizados por Miñano.

Interesa considerar, por último, que la sátira de La Linterna Mágica no pretende solo desenmascarar al enemigo político, pues al descorrer el velo que oculta la realidad del presente apunta tanto al lacayo como al ministro, todo el público / lector participa de la mascarada. En todo caso, no se trata tanto de pintar tipos reconocibles del entorno urbano a la manera que lo hará luego el costumbrismo, sino de seguir la senda de la sátira ilustrada para descubrir los defectos y las costumbres inmorales de la nueva sociedad constitucional, donde triunfan tipos como «el cambia-colore», «el liberal quieras que no» o «el liberal de poco acá». De hecho, podría considerarse que, en formato más ligero, persigue el mismo objeto que las cartas publicadas en $E l$ Censor:

Las Cartas del Madrileńo son una continua y severa crítica de todas las faltas y extravíos que se advierten en el sistema constitucional, tanto de parte de sus enemigos declarados, como de los que so color de amarle con exceso, sacan de quicio las sólidas y verdaderas bases en que se funda. («Explicación que da el autor de las cartas del Madrileńo sobre el verdadero sentido de la carta 13a», El Censor, 3 de marzo de 1821, 54).

¿Qué falló entonces para que La Linterna Mágica no alcanzase el éxito esperado? Creo que, en esta ocasión, la galería caricaturesca no funcionó, en primer lugar, porque como señalaba Maese Pedro el público gustaba de «un poco más de movimiento y de verdad", es decir, de una sátira más colorida, más agresiva, en la que fueran más explicitas las alusiones a personajes reconocibles y, luego, porque la denuncia alcanzaba a la generalidad. Así opina la Periódico-

26. Claude Morange, op. cit., pp. 34-38. 
manía en su no 16, cuando escribe: «Nada de luces, ni medias luces. Está visto. Hacen mal de ojo. Ha dado en tres números graciosas escenas, pero como no ha personalizado, no ha prosperado» y remata su interpretación con el siguiente epitafio:

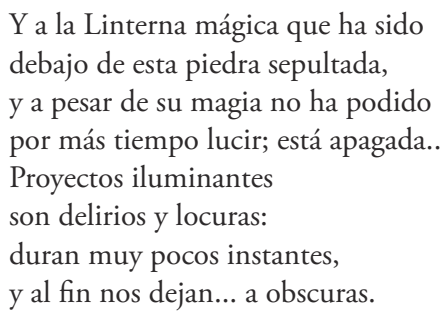

En fin, fuera obra de Miñano o de un imitador, el público no gustó de las maravillas que se le proponía vislumbrar. En ese mundo encantado, en esa mascarada infernal de la nueva experiencia constitucional, alumbrada por $L a$ Linterna Mágica, todos sin excepción -fueran del color que fueran- quedaban al descubierto y el público debió de sentirse incomodado al contemplar una realidad que, lejos de enfocar a personalidades, desnudaba a todos por igual. 
